Working Paper Series no. 11

Socioeconomics and Policy Program

\title{
Assessing Adoption Potential of New Groundnut Varieties in Malawi
}

H A Freeman, P J A van der Merwe, P Subrahmanyam, AJ Chiyembekeza, and W Kaguongo

International Crops Research Institute for the Semi-Arid Tropics 
Citation: Freeman, H.A., van der Merwe, P.J.A., Subrahmanyam, P., Chiyembekeza, A.J., and Kaguongo, W. 2002. Assessing adoption potential of new groundnut varieties in Malawi. Working Paper Series no. 11. P O Box 39063, Nairobi, Kenya: Socioeconomics and Policy Program, International Crops Research Institute for the Semi-Arid Tropics. 16 pp.

Titles in the Working Paper Series aim to disseminate information and stimulate feedback from the scientific community. A large number of similar and informal publications have been distributed by ICRISAT's Socioeconomics and Policy Program under various titles: Progress Reports, Discussion Papers, and Occasional Papers.

\begin{abstract}
This study uses farmers who hosted on-farm trials and demonstrations involving three new groundnut varieties in Malawi to assess their acceptability and adoption potential. It also examines patterns of seed diffusion among trial farmers as well as among non-trial farmers who were members of seed banks. The study shows that trial follow-up surveys provide a cost-effective approach for assessing early adoption and providing feedback to researchers. Although this study is useful it needs to be perceived and designed as one of several studies that help researchers understand the complexity of farmers' adoption decisions.
\end{abstract}

\title{
Résumé
}

Evaluation du potentiel d'adoption de nouvelles variétés d'arachide au Malawi. Cette étude s'appuie sur les paysans qui ont accueilli les essais et les démonstrations en milieu paysan concernant trois nouvelles variétés d'arachide au Malawi, pour mesurer leur potentiel d'acceptabilité et d'adoption. Elle examine également les systèmes de distribution parmi les paysans qui ont pris à part l'essai et ceux qui n'y ont pas participer et qui étaient membres de banque céréalières. L'étude montre que les enquêtes de suivi menées sur l'essai ont permis d'élaborer une approche avantageuse qui permet d'évaluer l'adoption rapide et de fournir un feed-back aux chercheurs. Quoique utile, cette étude doit être considérée comme une des nombreuses recherches qui visent à aider les chercheurs à comprendre la complexité des décisions prises par les paysans en matière d'adoption. 


\section{Assessing Adoption Potential of New Groundnut Varieties in Malawi}

H A Freeman, P J A van der Merwe, P Subrahmanyam, A J Chiyembekeza, and W Kaguongo

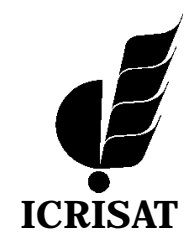

International Crops Research Institute for the Semi-Arid Tropics

P O Box 39063, Nairobi, Kenya 


\section{Authors}

H A Freeman

P O Box 39063, Nairobi, Kenya

P J A van der Merwe P O Box 1096, Lilongwe, Malawi

P Subrahmanyam P O Box 1096, Lilongwe, Malawi

A J Chiyembekeza

P O Box 1096, Lilongwe, Malawi

W Kaguongo

P O Box 39063, Nairobi, Kenya

\section{Acknowledgments}

The authors are grateful to R B Jones and B R Ntare for comments on earlier versions of this paper. The support of BMZ/GTZ and ICRISAT in funding the project is gratefully acknowledged.

C2002 by the International Crops Research Institute for the Semi-Arid Tropics (ICRISAT)

All rights reserved. Except for quotations of short passages for the purpose of criticism and review, no part of this publication may be reproduced, stored in retrieval systems, or transmitted in any form or by any means, electronic, mechanical, photocopying, recording or otherwise, without prior permission from ICRISAT. It is hoped that this copyright declaration will not diminish the bona fide use of research findings in agricultural research and development.

The opinions expressed in this publication are those of the authors and not necessarily those of ICRISAT. The designations employed and the presentation of material in this publication do not imply the expression of any opinion whatsoever on the part of ICRISAT concerning the legal status of any country, territory, city or area, or concerning the delimitation of its frontiers or boundaries. Where trade names are used, this does not constitute endorsement of or discrimination against any product by the Institute.

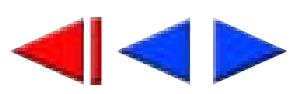




\section{Contents}

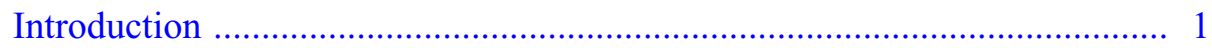

On-farm Trials and Demonstrations ....................................................... 2

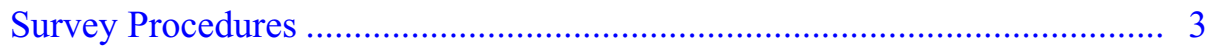

Farmer Characteristics .............................................................................. 4

Patterns of Adoption ............................................................................ 5

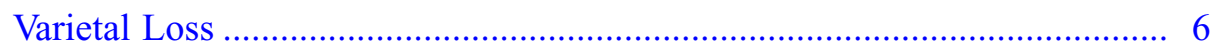

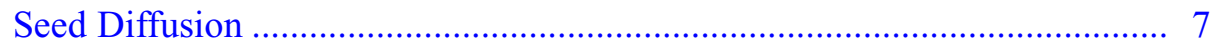

Farmers' Perceptions of the Improved Varieties ............................................ 9

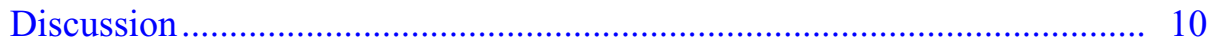

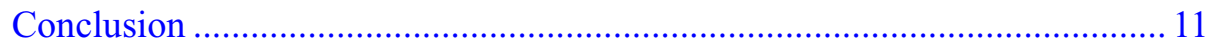

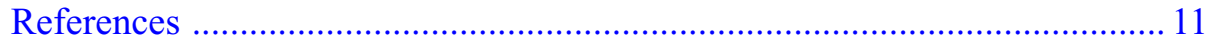




\section{Introduction}

Research efforts to develop and disseminate new agricultural technologies frequently involve multidisciplinary teams of scientists and activities are typically conducted over several years. Monitoring farmers' perceptions and obtaining feedback about the performance of new technologies, especially when experiments are conducted on farmers' fields, is therefore necessary for improving the efficiency of research, technology exchange, and information flow to policy makers. On-farm research has been used in crop improvement programs to evaluate and verify performance of new crop varieties on farmers' fields, identify farmers' preferences on varietal traits, quantify the effects of pests and diseases, and identify production and adoption constraints. On-farm research can also be used as a strategic research tool to predict adoption potential by monitoring farmers' opinions or assessing the acceptability of new technology as it is being developed and tested.

This paper assesses the acceptability of new groundnut (Arachis hypogaea L.) varieties through follow-up studies with farmers who participated in on-farm trials or demonstrations in Malawi. The objective is to determine whether trial farmers continued using the new groundnut varieties and crop management practices tested on their farms and assess the patterns of dissemination of the new varieties among farmers who continued growing them after the trials ended. Using trial farmers in follow-up studies provides a cost-effective and quick method to assess adoption potential over a range of agroecological zones, particularly of open-pollinated crop varieties such as groundnut (David et al. 1997).

Groundnut is the most important legume grown in Malawi in terms of the total production and area under cultivation (Chiyembekeza et al. 1998). The crop provides an important source of food and cash income for smallholder farmers and until the mid-1990s was a key export crop (Babu et al. 1994, Dzilankhulani et al. 1998). However, production and export of the crop has steadily declined since the late 1980s as a result of declining area under production and reduced yields (Freeman et al. 1999). The crop varieties examined in this paper are the outcome of research efforts undertaken by the Southern Africa Development Community/International Crops Research Institute for the Semi-Arid Tropics (SADC/ICRISAT) Groundnut Project, a regional initiative established to address concerns about low groundnut yields and other important production constraints in the region. The principal purpose of the project was to support national groundnut research programs in the SADC member countries through continuous supply of improved germplasm for evaluation and utilization in their breeding programs and broadening of the pool of genetic resources in the region (Subrahmanyam et al. 1998). Early research efforts focused on developing improved genetic materials with priority placed on traits such as high yield potential, early maturity, and resistance to diseases of major importance, particularly early leaf spot (Cercospora arachidicola Hori.) and rosette. In 1996 the focus of the project shifted to technology transfer activities emphasizing on-farm evaluation of new varieties and crop management practices through on-farm variety trials and demonstrations as well as seed production. These activities were carried out to introduce farmers to the new groundnut varieties developed in earlier phases of the project, verify their performance under farmers' conditions, and get feedback from farmers about those varieties that best met their needs. 


\section{On-farm Trials and Demonstrations}

In Malawi several on-farm variety trials, variety demonstrations, and diagnostic agronomy trials were implemented starting in 1996. The on-farm variety trials were designed and implemented by the national research and extension staff across a range of agroecological conditions in the country. The trials were laid out in a randomized complete block design with each trial replicated four times. Each genotype was planted on four ridges measuring $90 \mathrm{~cm} \times 6 \mathrm{~m}$. One seed was planted by planting station on top of the ridges at $15 \mathrm{~cm}$ apart. Variety demonstrations were spatially more diverse being planted over a wider geographical area and involved a larger number of farmers. The demonstrations were planted on five ridges, each ridge measuring $90 \mathrm{~cm} \times 5 \mathrm{~m}$. These demonstrations were managed by farmers and were used for farmers' evaluation of the new varieties as well as for seed production. In addition to the variety trials and demonstrations, yield gap and diagnostic agronomy trials were planted on farmers' fields. Both these trials were jointly planned and implemented by staff of the SADC/ICRISAT Groundnut Project and the national research program. Yield gaps were demonstrated in farmer-managed trials during the 1996/97 and 1997/98 cropping seasons. Twenty farmers from five villages, four from each village, were selected for the trials. Four treatments were applied in single replicate trials: farmer variety grown under farmer practice; farmer variety grown under recommended practice; new variety grown under farmer practice; and new variety grown under recommended agronomic practice. On-farm diagnostic trials were conducted during 1997/98 and 1998/99 cropping seasons. Trials were planted on farmers' fields in two Agricultural Development Divisions (ADDs). A split plot design with $2^{4}$ factorial arrangement of treatments and three replications per site was used. The plot factors were different sowing dates; sub-plot factors were improved variety, CG 7, and a local variety, Chalimbana; row widths of $90 \mathrm{~cm}$ and $60 \mathrm{~cm}$; and weeding once and twice. Treatments were completely randomized within sub-plots. The project also established seed banks in the villages where the yield gap trials were implemented. The stated objective of the seed bank was to make seeds of the new varieties available to farmers through the development of a sustainable seed multiplication and distribution system at the village level. ICRISAT provided the initial stock of groundnut seed to village committees who subsequently distributed seeds to other farmers. The seed committees issued seeds to farmers on loan with the requirement that farmers repay $200 \%$ in seed after harvest.

The study monitored farmers' use of three improved groundnut varieties, CG 7, ICGV-SM 90704, and JL 24, and improved crop management practices. The influence of seed banks, which involved only CG 7 on patterns of diffusion of the variety was also examined. In terms of their botanical classification, CG 7 and ICGV-SM 90704 are Virginia types while JL 24 is a Spanish type. CG 7 has a bunch growth habit with alternate branching pattern, matures in 120-130 days, is drought tolerant, and has red uniform seed with 48-50\% oil content. ICGV-SM 90704 has a spreading bunch growth habit, matures in 120-140 days, is resistant to rosette, and has tan seed with 45-48\% oil content. JL 24 has bunch growth habit, matures in 90-110 days, is drought tolerant, has no seed dormancy, and has tan seed with $48 \%$ oil content. The variety trials and demonstrations had three varieties, CG 7, ICGVSM 90704, and JL 24 while the yield gap and diagnostic agronomy trials had only one variety, CG 7. Chalimbana, a Virginia type that is widely grown in Malawi, was used as a control for all trials and demonstrations. It has a runner growth habit, matures in 140-150 days, has large, tan seed with 45\% oil content. Average seed yield reported in demonstration plots at 22 sites in the country was $1262 \mathrm{~kg} \mathrm{ha}^{-1}$ 
for CG 7, $1260 \mathrm{~kg} \mathrm{ha}^{-1}$ for ICGV-SM 90704, and $1087 \mathrm{~kg} \mathrm{ha}^{-1}$ for JL 24. In contrast average yield of the local control, Chalimbana, was $623 \mathrm{~kg} \mathrm{ha}^{-1}$ (SADC/ICRISAT 1998).

\section{Survey Procedures}

The survey involved farmers who had participated in on-farm trials and demonstrations during 1996/ 97 to 1998/99 cropping seasons. Data were collected from 59 farmers between July and August 1999 in 16 Extension Planning Areas (EPAs) in Lilongwe and Kasungu ADDs which together account for over $70 \%$ of the total area under groundnut production in Malawi. The sample for the survey was drawn from lists of farmers in project records while field extension staff assisted in locating farmers. All farmers who were interviewed had participated in a trial or demonstration for at least one complete season. Those who participated in the variety trial or demonstration received three new varietiesCG 7, ICGV-SM 90704, and JL 24-while those in the yield gap and diagnostic agronomy trials received only CG 7. All the farmers in the sample reported growing CG 7, 40 farmers grew ICGV-SM 90704, and 41 farmers grew JL 24. Data were also collected from an additional 53 farmers who were members of seed banks but had not participated in a trial or demonstration. This was done in order to get better insights of the effects of seed banks on the patterns of diffusion of CG 7.

On an average, farmers participated for two years in the trials and for one year in the demonstrations. Farmers who hosted variety trials and demonstrations received $2 \mathrm{~kg}$ and $1.5 \mathrm{~kg}$ seed respectively of each new variety while those in the yield gap and diagnostic agronomy trials received $2 \mathrm{~kg}$ seed of CG 7. Using recommended seed rates of $90 \mathrm{~kg} \mathrm{ha}^{-1}$ for CG 7 and ICGV-SM 90704 and 50 $\mathrm{kg} \mathrm{ha}^{-1}$ for JL 24 the seeds distributed were sufficient to plant $300 \mathrm{~m}^{2}$ each of CG 7 and ICGV-SM 90704 and $400 \mathrm{~m}^{2}$ of JL 24 in the variety trials. In the variety demonstration the quantities of seed distributed was sufficient to plant $200 \mathrm{~m}^{2}$ of CG 7 and ICGV-SM 90704 and $300 \mathrm{~m}^{2}$ of JL 24 .

Data were analyzed for 56 farmers who provided complete data. Of these, 34 farmers were in Kasungu ADD and 22 farmers in Lilongwe ADD. The number of farmers by type of trial is presented in Table 1. Seven farmers who participated in the trials or demonstrations were also members of seed banks.

\begin{tabular}{lccc}
\hline $\begin{array}{l}\text { Table 1. Distribution (number) of farmers by trials and demonstrations at two locations in } \\
\text { Malawi. }\end{array}$ & Kasungu & Lilongwe & Total \\
\hline Trial & 2 & 1 & 3 \\
\hline Variety trial & 26 & 12 & 38 \\
Variety demonstration & 5 & 6 & 11 \\
Diagnostic agronomy trial & 1 & 3 & 4 \\
Yield gap trial & 34 & 22 & 56 \\
\hline
\end{tabular}




\section{Farmer Characteristics}

A total $61 \%$ of the respondents were male farmers in Kasungu and Lilongwe (Table 2). Among female respondents, the majority (68\%) lived in male-headed households while $9 \%$ were de facto heads of households with migrant husbands and 23\% were de jure heads of households who were never married, divorced, or widowed. The average age of respondents was 43 years with no significant difference in the average age of male and female respondents. Over half of the respondents in the survey, particularly the male farmers, had at least primary education. In contrast female farmers were less likely to have been to school with about two-third of them reporting no formal education. The average family size was six members comprising an equal proportion of male and female members.

The average farm size in the survey was 2.25 ha. Farms in Kasungu tended to be larger on average than those in Lilongwe but the difference was not statistically significant. However, male respondents reported significantly larger average farm sizes compared to female respondents. Family labor supply

\section{Table 2. Characteristics of farm households at two locations in Malawi.}

\begin{tabular}{|c|c|c|c|}
\hline Description & Kasungu & Lilongwe & Total \\
\hline Respondents (number) & 34 & 22 & 56 \\
\hline \multicolumn{4}{|l|}{ Respondent (\%) } \\
\hline Male & 71 & 46 & 61 \\
\hline Female & 29 & 54 & 39 \\
\hline \multicolumn{4}{|l|}{ Age of respondent (years) } \\
\hline Average age & 43 & 42 & 43 \\
\hline Standard deviation & 14 & 14 & 14 \\
\hline Median & 40 & 40 & 40 \\
\hline \multicolumn{4}{|l|}{ Education of respondent (\%) } \\
\hline None & 41 & 41 & 41 \\
\hline Primary & 59 & 55 & 57 \\
\hline Adult & 0 & 5 & 2 \\
\hline Average household size (number) & 3 & 3 & 6 \\
\hline \multicolumn{4}{|l|}{ Farm size (ha) } \\
\hline Owned & 2.50 & 1.86 & 2.25 \\
\hline Standard deviation & 1.13 & 1.79 & 1.44 \\
\hline Median & 2.02 & 1.21 & 2.02 \\
\hline Rented & 0.18 & 0.31 & 0.23 \\
\hline Standard deviation & 0.40 & 0.76 & 0.57 \\
\hline Median & 0.00 & 0.00 & 0.00 \\
\hline Total & 2.68 & 2.17 & 2.48 \\
\hline Standard deviation & 1.20 & 2.42 & 1.78 \\
\hline Median & 2.40 & 1.62 & 2.02 \\
\hline \multicolumn{4}{|l|}{ Respondents (\%) reporting } \\
\hline Hiring labor & 47 & 41 & 45 \\
\hline Deficit in maize production & 38 & 50 & 43 \\
\hline Growing tobacco & 91 & 59 & 79 \\
\hline
\end{tabular}


was the dominant source of farm labor but $45 \%$ of respondents reported hiring temporary labor to supplement their family labor supply.

All respondents cultivated maize (Zea mays L.), the main staple food in the survey area. However, $43 \%$ of the respondents reported that they did not produce adequate maize to meet their household requirements for an entire year. Although there was no significant difference in the proportion of farmers who reported producing adequate maize for a year in Kasungu and Lilongwe a higher proportion of female respondents reported producing inadequate quantities of maize to meet household needs compared to male respondents in both locations. Tobacco (Nicotiana tabacum L.), grown by $79 \%$ of all respondents, was a major cash crop in both areas although it was more frequent in Kasungu. On average about 0.46 ha was allocated to tobacco plots with no significant difference across the two locations.

Several factors suggested that the trials and demonstrations were biased towards better-off farmers. Thus the results might not be representative of the farm population in the area. The estimated average farm size of 2.5 ha reported in the survey was about twice the average farm size of 1.5 ha reported in a random survey of households in both locations (Dzilankhulani et al. 1998). Only 2\% of respondents in the survey reported producing sufficient maize to meet household requirements for less than 3 months compared to national estimates of $10 \%$. Such biased responses might reflect the role of extension staff in selecting farmers for trials and demonstrations. Extension agents selected over 90\% of the farmers for participation in the trials and demonstrations.

\section{Patterns of Adoption}

Two criteria were used to assess patterns of adoption in this study. The first considered whether a farmer continued growing a test variety after the trials ended (David et al. 1997). A second indicator, intended to capture the intensity or extent of adoption, measured the area planted to the new variety after the trials ended. More than half of the respondents in the survey continued growing the new varieties after end of the on-farm trials and demonstrations. Specifically, $80 \%$ of trial farmers continued growing CG 7, 63\% continued growing ICGV-SM 90704, and 51\% continued growing JL 24 (Table 3). This observed pattern of adoption with farmers showing a strong preference and higher level of acceptance for CG 7 followed by ICGV-SM 90704 and JL 24 is consistent across both regions of Kasungu and Lilongwe ADDs. Farmers in variety trials were just as likely to continue growing the new varieties as those in demonstrations indicating that the type of on-farm intervention was not an important determinant in farmer adoption behavior. A higher proportion of farmers in Kasungu continued growing each of the new varieties compared to Lilongwe but these regional

Table 3. Farmers who continued to grow improved groundnut varieties after trials ended.

\begin{tabular}{lccccccc}
\hline & \multicolumn{2}{c}{ CG 7} & & \multicolumn{2}{c}{ ICGV-SM 90704 } & & \multicolumn{2}{c}{ JL 24 } \\
\cline { 2 - 4 } \cline { 6 - 8 } Location & No. & $\%$ & & No. & $\%$ & No. & $\%$ \\
\hline Kasungu & 34 & 82 & 28 & 64 & 27 & 56 \\
Lilongwe & 22 & 77 & 12 & 58 & 14 & 43 \\
Total & 56 & 80 & 40 & 63 & 41 & 51 \\
\hline
\end{tabular}


variations were not statistically significant. The pattern of adoption among female respondents was similar to the pattern in the entire sample with female respondents just as likely to continue growing the new groundnut varieties as male respondents.

Disaggregating the data by membership in seed banks indicated that all farmers who hosted trials and were members in seed banks continued to grow CG 7. This compares with $78 \%$ of farmers who continued to grow the variety but were not members of seed banks (Table 4). Similarly, a higher proportion of respondents in villages with a seed bank continued to grow CG 7 compared to those in villages without seed bank. However, membership in seed banks or the location of seed bank in a village did not significantly influence the decision to continue growing CG 7.

Among farmers who continued growing the new groundnut varieties, the indicative proxy for the intensity of adoption was the comparison of the reported area under the test variety and the area cultivated one year after the trials ended (Table 5). The data on area cultivated in the trial year indicated that farmers followed the recommended seeding rates for CG 7 but used higher seeding rates to achieve even higher yields with closely-spaced ridges for ICGV-SM 90704 and JL 24 (Chiyembekeza et al. 1998). The data also indicated an increase in the area under all the new groundnut varieties implying increased adoption following the trials. Farmers allocated twice as much land to ICGV-SM 90704 and JL 24 and about three times as much land to CG 7 in the year after the trials ended.

\section{Varietal Loss}

The survey indicated that farmers stopped growing the new groundnut varieties because of socioeconomic, trial related, and agroecological factors that may or may not be specific to a variety. Socioeconomic factors, particularly consumption of seed stock, were most frequently cited as the most important reason for farmers having stopped growing the new varieties (Table 6). In a few cases,

\section{Table 4. Farmers (\%) who continued to grow groundnut variety CG 7 by seed bank membership and villages ${ }^{1}$.}

\begin{tabular}{lcccc}
\hline Description & $\begin{array}{c}\text { Seed bank } \\
\text { member } \\
(\mathrm{n}=7)\end{array}$ & $\begin{array}{c}\text { Non-seed bank } \\
\text { member } \\
(\mathrm{n}=49)\end{array}$ & $\begin{array}{c}\text { Village with } \\
\text { seed bank } \\
(\mathrm{n}=12)\end{array}$ & $\begin{array}{c}\text { Village without } \\
\text { seed bank } \\
(\mathrm{n}=44)\end{array}$ \\
\hline Continued & 100 & 78 & 92 & 77 \\
Did not continue & 0 & 22 & 8 & 23 \\
\hline $1 . \mathrm{n}=$ number of farmers. & & & & \\
\hline
\end{tabular}

Table 5. Comparison of average area under improved groundnut varieties.

\begin{tabular}{lccc}
\hline Description & CG 7 & ICGV-SM 90704 & JL 24 \\
\hline Area in trial year (ha) & $0.02(56)^{1}$ & $0.01(40)$ & $0.01(41)$ \\
Area one year after trial (ha) & $0.07(45)$ & $0.02(25)$ & $0.02(21)$ \\
\hline 1. Number of farmers is given in parenthesis. & & & \\
\hline
\end{tabular}


Table 6. Farmers (\%) who did not continue to grow improved groundnut varieties after trials ended for various reasons ${ }^{1}$.

\begin{tabular}{lccc}
\hline Reasons & $\begin{array}{c}\text { CG } 7 \\
(\mathrm{n}=11)\end{array}$ & $\begin{array}{c}\text { ICGV-SM 90704 } \\
(\mathrm{n}=13)\end{array}$ & $\begin{array}{c}\text { JL 24 } \\
(\mathrm{n}=15)\end{array}$ \\
\hline Socioeconomic & $\mathbf{5 5}$ & $\mathbf{4 6}$ & $\mathbf{4 7}$ \\
Ate all seeds & 36 & 31 & 20 \\
Plot unattended due to sickness & 0 & 0 & 0 \\
Unacceptable seed size & 9 & 0 & 13 \\
Concentrated with other crops & 9 & 8 & 7 \\
Seed stolen & 0 & 8 & 7 \\
Trial related & $\mathbf{1 8}$ & $\mathbf{2 3}$ & $\mathbf{1 3}$ \\
Seed lost in mixture & 0 & 8 & 0 \\
Seed did not germinate & 0 & 0 & 7 \\
Seed taken by extension/research staff & 9 & 8 & 7 \\
Low yielding & 9 & 8 & 0 \\
Agroecological & $\mathbf{2 7}$ & $\mathbf{3 1}$ & $\mathbf{4 0}$ \\
Crop destroyed by drought & 9 & 8 & 7 \\
Seed destroyed by pests & 18 & 23 & 33 \\
\hline 1. $\mathrm{n}=$ number of farmers. & & & \\
\hline
\end{tabular}

farmers reported "dis-adoption" of CG 7 (9\%) and JL 24 (13\%) because of factors related to varietal characteristics such as dislike for seed size. Agroecological factors were also important in explaining varietal loss of all varieties with damage by pests cited as most likely reason for loss of seed stock.

The results did not suggest any reason to believe that farmers who consumed their seeds were most food insecure. On the contrary, three out of the four farmers who consumed their seed stocks reported producing sufficient maize for their household requirement. In all these cases seed stocks were consumed because the farmers believed that they could get fresh seed stock from extension staff.

\section{Seed Diffusion}

The majority of respondents (68\%) did not distribute seed of the new varieties; $25 \%$ of respondents shared seed of CG 7 with other farmers, 15\% shared JL 24, and 8\% shared ICGV-SM 90704 (Table 7). Those respondents who shared seed usually distributed seed of ICGV-SM 90704 and JL 24 to one farmer and that of CG 7 to an average of three farmers. Seed distribution to any one farmer usually involved small quantities of about $1 \mathrm{~kg}$ of ICGV-SM 90704 and JL 24 and $3 \mathrm{~kg}$ of CG 7. The data also

Table 7. Seed diffusion of improved groundnut varieties.

\begin{tabular}{lcccc}
\hline Variety & $\begin{array}{c}\text { Total } \\
\text { farmers }\end{array}$ & $\begin{array}{c}\text { Farmers (\%) } \\
\text { distributing seed }\end{array}$ & $\begin{array}{c}\text { Average number of } \\
\text { persons given seed } \\
\text { by each farmer }\end{array}$ & $\begin{array}{c}\text { Quantity of seed } \\
\text { given per person } \\
\text { (kg) }\end{array}$ \\
\hline CG 7 & 56 & 25 & 3 & 3.3 \\
ICGV-SM 90704 & 39 & 8 & 1 & 0.8 \\
JL 24 & 40 & 15 & 1 & 1.1 \\
\hline
\end{tabular}


suggested that in the few cases where respondents shared seed, distribution started about two or three years after the farmer first grew the variety.

Farmers who participated in seed banks were less likely to distribute seed of CG 7 to other farmers compared to those who were not members in seed banks (Table 8). This might be due to the small sample size of trial farmers who were also members in seed banks. Analysis of other farmers who did not participate in the trials but were members of seed banks suggested that seed bank members were more likely to distribute seed compared to farmers who were not members in seed banks.

Seed distribution tended to be restricted to farmer-to-farmer exchange in the same village (61\%) or in a neighboring village (28\%). Distribution was $33 \%$ to relatives in the same village and $11 \%$ to relatives outside the village of the farmers who shared seed. Among farmers who distributed seeds of the new groundnut varieties, $89 \%$ gave the seeds as gift particularly to relatives and other farmers with whom they shared close social networks within the village. About one-third (33\%) of the respondents bartered seeds of the new groundnut varieties for seeds of other crops while about one-fifth (17\%) sold seeds to other farmers.

The pattern of responses for non-distribution of seed was consistent for all the three new groundnut varieties (Table 9). Farmers cited inadequate quantities of seed as the most frequent reason for not distributing seeds. About one-third of the respondents did not distribute the new groundnut varieties because no one asked the respondents for seeds while about $20 \%$ wanted to increase their seed stock.

The majority of respondents ( $82 \%)$ knew where to get fresh seed stock. Extension was cited as the main source of fresh seed particularly in villages without seed banks (Table 10). About 40\% of respondents cited other farmers in their village as a source of fresh seed implying that seed banks

Table 8. Percentage of farmers distributing seed of groundnut variety CG 71.

\begin{tabular}{lcccc}
\hline Description & $\begin{array}{c}\text { Trial farmers } \\
\text { in seed bank } \\
(\mathrm{n}=7)\end{array}$ & $\begin{array}{c}\text { Trial farmers } \\
\text { not in seed bank } \\
(\mathrm{n}=49)\end{array}$ & $\begin{array}{c}\text { All farmers } \\
\text { in seed bank } \\
(\mathrm{n}=49)\end{array}$ & $\begin{array}{c}\text { All farmers } \\
\text { not in seed bank } \\
(\mathrm{n}=63)\end{array}$ \\
\hline Distributed seed & 14 & 26 & 43 & 29 \\
Did not distribute seed & 86 & 74 & 57 & 71 \\
\hline $1 . \mathrm{n}=$ number of farmers. & \multicolumn{5}{|}{} \\
\hline
\end{tabular}

Table 9. Percentage of farmers not sharing groundnut seed for various reasons ${ }^{1}$.

\begin{tabular}{lccc}
\hline Reasons & $\begin{array}{c}\text { CG 7 } \\
(\mathrm{n}=43)\end{array}$ & $\begin{array}{c}\text { ICGV-SM 90704 } \\
(\mathrm{n}=34)\end{array}$ & $\begin{array}{c}\text { JL 24 } \\
(\mathrm{n}=33)\end{array}$ \\
\hline Did not have enough seed & 61 & 53 & 52 \\
Had small quantities & 41 & 32 & 33 \\
Wanted to increase seed stocks & 21 & 23 & 20 \\
No one asked for seed & 26 & 32 & 33 \\
Awaiting advice from extension staff & 13 & 13 & 13 \\
\hline 1. $\mathrm{n}=$ number of farmers. & & \\
\hline
\end{tabular}


Table10. Farmers (\%) obtaining fresh seed from various sources ${ }^{1}$.

\begin{tabular}{lccc}
\hline Source & $\begin{array}{c}\text { Village with } \\
\text { seed bank } \\
(\mathrm{n}=8)\end{array}$ & $\begin{array}{c}\text { Village without } \\
\text { seed bank } \\
(\mathrm{n}=38)\end{array}$ & $\begin{array}{c}\text { Total } \\
(\mathrm{n}=46)\end{array}$ \\
\hline Extension staff & 38 & 76 & 70 \\
Farmer in the village & 38 & 0 & 7 \\
Farmer outside the village & 0 & 3 & 2 \\
Seed bank outside village & 0 & 3 & 2 \\
Chitedze Research Station & 13 & 11 & 11 \\
Local market & 13 & 8 & 9 \\
\hline 1. $\mathrm{n}=$ number of farmers. & & & \\
\hline
\end{tabular}

tended to enhance farmer-to-farmer seed exchange in the villages where they were located. Very few farmers $(2 \%)$ cited seed banks outside their village as a source of fresh seed. This suggested that seed banks played a limited role in enhancing seed diffusion outside the villages in which they were located.

\section{Farmers' Perceptions of the Improved Varieties}

The survey collected data of farmers' perceptions of the three new improved groundnut varieties and the control over a range of plant traits. Median ranking of farmers' overall preference indicated that CG 7 was the most preferred variety followed by JL 24 and ICGV-SM 90704 (Table 11). Farmers also preferred all the new varieties to Chalimbana, the local control. In terms of individual ranking of traits, CG 7 was highly preferred because of its high yield, good taste, less cooking time, and drought tolerance while JL 24 was rated highly because of its early maturity.

\section{Table 11. Median ranking of improved groundnut varieties and local check}

\begin{tabular}{lcccc}
\hline Trait & CG 7 & ICGV-SM 90704 & JL 24 & $\begin{array}{c}\text { Chalimbana } \\
\text { (local check) }\end{array}$ \\
\hline Good taste & 1 & 3 & 2 & 4 \\
Cooks fast & 1 & 3 & 2 & 4 \\
Large seed size & 2 & 3 & 4 & 1 \\
Easily sold & 2 & 3 & 3 & 1 \\
Early maturing & 2 & 2 & 1 & 4 \\
High yielding & 1 & 3 & 2 & 4 \\
Tolerant to insect pests & 2 & 3 & 2 & 2 \\
Disease resistant & 2 & 2 & 3 & 4 \\
Drought tolerant & 1 & 2 & 2 & 4 \\
\multicolumn{1}{c}{ Overall ranking } & 1 & 3 & 2 & 4 \\
\hline
\end{tabular}

1. Ranking is on $1-4$ scale, where $1=$ best and $4=$ poorest, based on perceptions of 37 farmers. 
Kendall's W test was used to further discriminate farmers' preference ranking where the result from the median test was not conclusive. This result indicated that CG 7 was ranked higher than ICGV-SM 90704 on early maturity while JL 24 was ranked higher than ICGV-SM 90704 on drought tolerance.

Almost all farmers (91\%) cited positive impacts, particularly increased food supply, from growing the new varieties. Provision of early food and increased cash were also cited but these were less important.

\section{Discussion}

The results from this study suggested a high level of acceptability of the improved groundnut varieties among farmers who were exposed to them in on-farm variety trials and demonstrations. The study also implied differential patterns of adoption among the three varieties. CG 7 demonstrated the highest level of acceptance and potential for adoption followed by ICGV-SM 90704 and JL 24 across all regions. The lack of significant differences in adoption behavior between male and female farmers suggested that women farmers were just as likely to adopt the new groundnut varieties as were male farmers. A likely explanation for this is that the new technologies were consistent with women farmers' resource level and met their technology needs. It is likely that the observed differences in adoption patterns reflected farmers' appreciation of the characteristics of CG 7 compared to ICGV-SM 90704 and JL 24. But it is equally plausible that the differences in adoption patterns was a reflection of farmers' familiarity with CG 7 having been exposed to it for a much longer period through the activities of other development agencies in Malawi. Farmers might also have underestimated the performance of the other groundnut varieties because they only demonstrated superior performance under specific conditions. For example, since the incidence of rosette was low during the years of testing farmers were likely to underestimate the yield performance of the rosette resistant variety ICGV-SM 90704. In years when there were outbreaks of rosette (such as in 1994/95 and 1999/2000) ICGV-SM 90704 consistently out yielded CG 7 and JL 24.

Farmers stopped growing the new groundnut varieties for several reasons. Some farmers consumed their seed stock, even of preferred varieties, because they were under pressure to satisfy their subsistence needs. Other farmers who were not necessarily food insecure consumed their seed stocks because they perceived that they could get fresh supplies from extension. In other cases farmers stopped growing the new groundnut varieties because of reasons related to the characteristics of the varieties while some had difficulties maintaining their seed stock because of drought and pests. This assortment of reasons for discontinuing to grow the improved groundnut varieties points to the complexity of factors, often working simultaneously, that underlie farmers' adoption decisions. Adoption studies that will be useful for research planning need to recognize these complex interactions as well as their influence in conditioning farmers' adoption decisions.

The study showed that informal farmer-to-farmer diffusion was the main distribution mechanism for disseminating seeds of the new groundnut varieties. This process, however, was with a considerable lag, involved small quantities of seed, and limited to farmers within close social networks. This finding is consistent with other studies in Africa which suggest that the nature of informal seed networks and the dynamics of farmer-to-farmer seed diffusion may not necessarily 
facilitate rapid dissemination of new crop varieties (David and Sperling 1999). These concerns are even more relevant for groundnut because its low multiplication factor and high seeding rate imply that large seed stocks are required to enable farmers to keep seed of preferred varieties in their portfolio of varieties.

The lack of a significant relationship between membership in a seed bank and the decision to continue growing CG 7 suggested that this institutional innovation might have had a negligible influence on the dissemination of the improved groundnut variety. But this finding might be due to the small sample of farmers who both hosted trials and were members in seed banks. Nevertheless, the results for the entire sample suggest that the seed banks reduced search and negotiation cost for acquiring seeds of the new varieties within villages in which they were located. As a result the seed banks expanded the number of farmers who were able to grow the new groundnut varieties, increased the diversity of farmers' portfolio of groundnut varieties, and in some cases improved seed security.

The study, however, implied that community-based interventions, such as the seed banks, that rely on farmer-to-farmer diffusion need to broaden their initial "injection" of seed into informal seed networks so that they can take full advantage of getting seeds into the hands of as many farmers as possible. Efforts to speed diffusion of preferred varieties also need to exploit alternative market and non-market seed distribution mechanisms to ensure that seed is always available and available to everyone with an effective demand.

Farmers' assessment of the new varieties early in the research process provides useful feedback on farmers' priorities as well as problems with the new technologies. Such information is useful in refining technology development efforts and improving the two-way flow of information between researchers and farmers.

\section{Conclusion}

This study showed that follow-up studies with farmers who have been exposed to new varieties in onfarm trials and demonstrations provide a cost-effective approach for assessing the acceptability and adoption potential of new varieties. However, such studies should be designed as one of several studies that provide early assessment of farmer adoption decisions. In the medium term after the new varieties have been disseminated in the wider farming population it will be necessary to conduct formal surveys of technology adoption with larger probabilistic samples. Such studies offer useful insights into the complex factors influencing farmers' adoption decisions and provide useful feedback to researchers and policy makers.

\section{References}

Babu, S.C., Subrahmanyam, P., Chiyembekeza, A.J., and Ng'ong'ola, D. 1994. Impact of aflatoxin contamination on groundnut exports in Malawi. African Crop Science Journal 2:215-220.

Chiyembekeza, A.J., Subrahmanyam, P., Kisyombe, C.T., and Nyirenda, N.E. 1998. Groundnut: A package of recommendations for production in Malawi. Lilongwe, Malawi: Ministry of Agriculture and Irrigation. $14 \mathrm{pp}$. 
David, S., and Sperling, L. 1999. Improving technology delivery mechanisms: Lessons from bean seed systems research in eastern and central Africa. Agriculture and Human Values 16:381-388.

David, S., Wortmann, C., Kasozi, S., and Mugisha-Muteikka, M. 1997. Using trial follow-up surveys to assess varietal adoption: The case of beans. African Crop Science Journal 5:285-294.

Dzilankhulani, A.M., Tchale, H., and Boughton, D. 1998. Small-scale seed programs and adoption of groundnut technology: The case of CG 7 groundnut variety in Malawi. Lilongwe, Malawi: International Crops Research Institute for the Semi-Arid Tropics.

Freeman, H.A., Nigam, S.N., Kelley, T.G., Ntare, B.R., Subrahmanyam, P., and Boughton, D. 1999. The world groundnut economy: facts, trends, and outlook. Patancheru 502 324, Andhra Pradesh, India: International Crops Research Institute for the Semi-Arid Tropics. 52 pp.

SADC/ICRISAT Groundnut Project. 1998. Annual Progress Report. Lilongwe, Malawi: SADC/ ICRISAT Groundnut Project. 21 pp.

Subrahmanyam, P., van der Merwe, P.J.A., Russell, J.T., and Boughton, D.H. 1998. SADC/ ICRISAT Groundnut Project: An overview of accomplishments and future outlook. Pages 1-12 in Proceedings of the Malawi Government Groundnut Sector Stakeholder Workshop. Lilongwe, Malawi: Ministry of Agriculture and Irrigation. 


\section{About ICRISAT}

The semi-arid tropics (SAT) encompass parts of 48 developing countries including most of India, parts of southeast Asia, a swathe across sub-Saharan Africa, much of southern and eastern Africa, and parts of Latin America. Many of these countries are among the poorest in the world. Approximately onesixth of the world's population lives in the SAT, which is typified by unpredictable weather, limited and erratic rainfall, and nutrient-poor soils.

ICRISAT's mandate crops are sorghum, pearl millet, finger millet, chickpea, pigeonpea, and groundnut; these six crops are vital to life for the ever-increasing populations of the SAT. ICRISAT's mission is to conduct research which can lead to enhanced sustainable production of these crops and to improved management of the limited natural resources of the SAT. ICRISAT communicates information on technologies as they are developed through workshops, networks, training, library services, and publishing.

ICRISAT was established in 1972. It is one of 16 nonprofit, research and training centers funded through the Consultative Group on International Agricultural Research (CGIAR). The CGIAR is an informal association of approximately 50 public and private sector donors; it is co-sponsored by the Food and Agriculture Organization of the United Nations (FAO), the United Nations Development Programme (UNDP), the United Nations Environment Programme (UNEP), and the World Bank. 


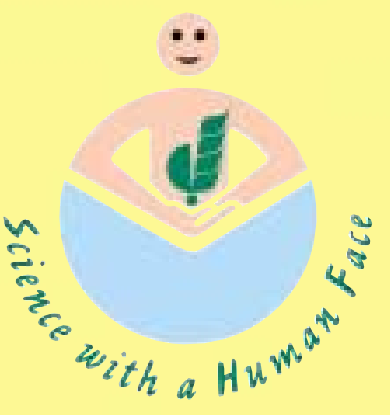

ICRISAT

International Crops Research Institute for the Semi-Arid Tropics

P O Box 39063, Nairobi, Kenya 